\title{
The Usage of Polygraph in the Department of Ministry of Interior of the Slovak Republic - A Retrospective View
}

\author{
Milan Kormoš* \\ Department of Applied Psychophysiology, Ministry of Interior, Presidium of Police Force, Criminalistics and Expertise Institute of Police Force, Europ ${ }^{e}$
}

Submission: December 20, 2017; Published: January 08, 2018

*Corresponding author: Milan Kormoš, Department of Applied Psychophysiology, Ministry of Interior, Presidium of Police Force, Criminalistics and Expertise Institute of Police Force, Europe, Email: 77.sirius@gmail.com

Keywords: Polygraph; History of Psychophysiological Detection of Deception of Ministry of Interior of the Slovak Republic; Ministry of Interior of Slovak Republic; History of Using the Polygraph

Abbreviations: AIAAP: Acxiton International Academy of Applied Psychophysiology; APA: American Polygraph Association; BAI: Behavioral Assessment Institute

\section{Opinion}

The history of the usage of polygraph in the department of Ministry of Interior of the Slovak republic has started to be written on 6th March 1998. Back then, selected personnel of the Ministry of Interior commenced under the guidance of long-time specialist in the area of work with the polygraph from the United states a special educational and training programme in the field of gaining experience with the polygraph with the perspective of using its results for the needs of individual units in the structure of Ministry of Interior. The decision to impose a polygraph into the arsenal of resources in the fight against antisocial activity was a logical result of affairs in the society, which was permanently confronted with abrupt rise in criminality. The then social atmosphere created an almost uncontrollable space, in which under the influence of changing socioeconomic affairs there is an expansion of different forms of illegal activities.

The main idea of the newly created specialized workplace under the name department of special psychology was the extension of palette of existing instruments in the department of clarification of criminal activity through the realization of psychophysiologic detection of deception by using an appropriate technical device. An expected general streamline and shortening of the process of investigation and clarification will be reached. After the completion of educational and training programme under the conduct of AIAAP (Acxiton International Academy of Applied Psychophysiology) Houston, Texas, the activity of the workplace was practically directed into two levels.
Area of criminal work and area of screening (personal) work. This fact is even addressed in the historically first document regarding the activity of department of special psychology under the name Regulation of Interior secretary of SR no. 57/1998 [1]. The mentioned document basically adjusted the conditions of performing a special psychophysiological test, it specified the workplace as an independent organizational unit in the structure of Ministry of Interior. At the same time it dealt with the areas of its activity, characterized the subject of investigation and set the rules for the final statement in the form of investigation report.

The activity of the workplace has relatively dynamically started and the workplace established itself in a short time in the structures of the Ministry of Interior. The department during the realization of its commitment commenced a targeted presentation of its activities with the goal to reach a widespread awareness of the specialized public about its existence. Professional presentations, during which the personnel of the department demonstrated expertial samples of their activity in front of the selected subjects caused a state, that the department of special psychology almost since the beginning of its activity solved requirements of different non-department subjects or subjects from private sphere for polygraph testing. Multiple units of civil service and corresponding force departments became applicants for test, among which belonged not only Bureau of Customs, Ministry of Finance or Ministry of Defence. Dominant, despite that, remained the effort to realize mainly 
test applications from individual units of Ministry of Interior. As the workplace was the only one in Slovakia in the department of Ministry of Interior, it nationwide covered the realization of requirements within the whole Slovak republic.

The examination of acquired expertial knowledge, abilities and first practical experiences was in that time even the active participation of the department personnel of special psychology in clarification of a case of particular concern, which was the contract killing of former secretary of industry and economy from 11th January 1999. The then conducted polygraph test with the main suspect helped with assembling the mosaic of the case. The area of criminal work thus became for a certain period the preferred from the viewpoint of workload on the mentioned workplace. It covered almost every area of the spectre of valid law norms, mainly criminal code, in which the definitions of individual corpora delicti are mentioned. The personell of the department met with cases clasified as violent criminal acts against life and health, criminal acts against the family and young, criminal acts against freedom and human dignity, against property, economical criminal acts and others on a daily basis. The merit of activity always was the psychophysiological detection of deception of the suspected person, culprit, the aggrieved person or witness towards the currently investigated case.

The results of polygraph tests often became the magnetic needle on an imaginary compass, which navigated the whole process of investigation towards a faster clarification of the case. Especially in the so called "insufficient evidence cases" were the findings of psychophysiological detection of deception particularly valuable. They were often what brought "new wind into the sails" in the documentation and substantiation process. The second independent area of work of the department of polygraph testing became the area of screening. The heart of the work was centered into the segment of applicants selection for service in specialized departments of Police force of Slovak republic, examination of credibility and reliability of the tribal employees - policemen - serving within these departments, examination of policemen of other units within the organizational structure of Ministry of Interior, testing of policemen selected into personal reserves or the testing of selected civil employees of Ministry of Interior. Besides this activity, the personnel of the compartment of special psychology participated in the form of polygraph testing during selection procedures for positions in the vertical and horizontal levels of the organizational structure of the ministry in the framework of personal migration.

It is, for the completion of picture, desirable to mention, that the interest was centered into the area of reliability verification of the concerned subjects, breach of service and state secret, into area of leakage of service information, blackmail, cooperation with organized crime, the inclination to alcohol abuse or other addictive substances. A specific part of the work was polygraph testing of policemen, who were suspicious of committing various forms of criminal activities. The activity of the workplace was based on basic principles of work when performing psychophysiological detection of deception represented by professional organizations such as APA (American Polygraph Association), AIAAP (Axciton International Academy of Applied Psychophysiology), BAI (Behavioral Assessment Institute). The created legal background of the workplace clearly defined the main policies of its activity, which were anchored in a standard binding work procedure. The respect for the most important matter of polygraph testing, which is the voluntary principle, became the basic legal aspect. Any person falling under any point of some legal or internal documents governing the activity of the workplace had to (and must) agree to test execution.

Without given consent, it is impossible to conduct the test. The respect for the voluntary principle is therefore the respect for legal system principles. Besides that, everyone, who undergoes polygraph testing, had (and has) guaranteed another important fact, which is its standardized procedure using standardized means. Each of the tests has to be done by a certain, precisely defined procedure, which is anchored in a standard working procedure. An important aspect of polygraph testing in relation to the subject of investigation is the existence of the expertial level guarantee of the specialist, which is filled by completion of special preparation, mastering a prescribed amount of practical preparation lessons and completing a prescribed amount of realized tests under supervising leadership. Not only mastering the prescribed teaching and training programme, but also the consecutive permanent education of specialists is the guarantee of their steady professional development. The specialists of the workplace conducting polygraph testing have passed during the existence of the workplace several professional trainings and specialized programmes aimed at increasing their expertial qualification. In September 2005 and employee of the BAI institute from Texas performed an follow-up course in the area of forensic psychophysiology.

The same specialist once again offered his expertial and practical experiences in november 2012 in the frame of expertial training for the specialists of Ministry of Interior. Another advance in the expertness of employees happened after passing a special teaching and training course by one of the specialists from Lafayette Instrument Company in 2013. The last increase in the expertial level of employees in the form of an expertial course was in 2016 under the conduct of the leading specialist from Internal Polygraph School from Israel. In the intervening period the specialists have participated in additional expertial courses, seminars and conferences in Sochi, Columbia, Ukraine, Belarus and Poland... The Exchange of expertial experience and knowledge proceeded even within the so called "Triad", which is the grouping of specialists (polygraphists) from three countries-Poland, Czech republic and Slovakia, which happened in regular intervals, always on the territory of different country. The workplace conducting psychophysiological detection of deception has gone through several transformation processes in its nearly twenty years of activity. 
And during that time its position has changed in the organizational structure within the Ministry of Interior of SR, the legal background has changed, the conception of focus, different problems have been removed which occured during the activity in terms of determining the scope of competences of applicants regarding test execution, there have been changes in the system of its operation, the name of the workplace has changed repeatedly and in 2013 even its locality has changed. The workplace is currently a part of criminalistic and forensic expertise institution of the Presidium of Police force of Slovak republic under the name department of applied psychophysiology. It has risen from the first four employees to the actual number of seven specialists. The total number of employees is completed by one administration force. The actual document by which the activity of the department is regulated in present time is the Order no. 172 of the Interior secretary of SR from 29. November 2013 [2] regarding enhancement of personnel of designated units of Ministry of Interior of SR and Police force. It is a document which is preferentially focused on the area of personal work in the context of conducting polygraph testing. It manifests the endeavour of service organs to make the quality of personal work better in the department of Ministry of Interior and at the same time it documents the effort to eliminate different uncertainties and specific problems, which gradually occured during the years.

The mentioned document represents a line of uniform procedure when renewing the members of Police force of designated departments. It is a binding document bringing new rules, clear structure, clarifies the framework of mechanism functioning. It defines the basic reality, which of the objects of oragnizational structure is the intended department and it introduces these in their specific whole extent. It defines those departments, which have the duty of performing polygraph testing by its members, either tribal members or newly arriving (prospects) from other departments. From content focus of the document I choose the fact, that this in the corresponding part, among other things, deals with specific areas stated for the given determined department. That is, each of these departments, in regard to the specification of its activity, has clearly stated areas of testing, which are identical at each testing the member of given police department or policeman applying for a job in the given department. Each policeman, who has to take the polygraph test is informed about exact wording of the scope of testing in advance in written form (via e-mail) by a competent employee of the designated department.

Part of the basic information is the time span of tested period, which is generally set to 5 years (in distinctive cases the period is shortened in dependence on the length of functioning of the given policeman in the Police force). In 2016 the personnel of the department of applied psychophysiology conducted 649 polygraph tests within the screening. Only in 6 cases happened, that the test wasn't realized due to rejection by the given subject.
Besides that, there were 29 cases when the test wasn't realized due to different subjective and objective reasons (the employee withdrew the original application regarding personal transfer, family and health reasons....). Polygraph testing became a form of optimalization of personnel selection in the department of Ministry of Interior of SR. It is an instrument for choosing honest, reliable and loyal employees, policemen, in the process of filling work places in the structures of the Interior department. With its prophylactic aspect, it has a significant impact on reducing illegal activities of individuals. If often offers such information, which can not be obtained by a different method, which aren't included even in the personal papers.

The process of psychophysiological detection of deception has become a firm part of arsenal in the fight against antisocial activities in the recent years used during detection, documentation and clarification of illegal activity in the settings of the department of Ministry of Interior of Slovak republic. From the viewpoint of the outcome of examination on the polygraph in the context of the legal system, it isn't currently evaluated as proof. On the other side, from the point of view of objectivity it is necessary to mention, that the Act no. 301/2005 Collection of Laws, The Code of criminal procedure [3], doesn't mention, that the result from the polygraph can't be used as proof. It defines in the paragraph 119, section 2: "Everything can serve as evidence that can contribute to proper clarification of matter and what has been gained from evidence according to this act or according to a distinctive act". Therefore there aren't rare cases, when the bodies involved in criminal proceedings include the result form the polygraph as one of the elements, which forms a part of investigation file in a particular case. It is then on an individual assessment of prosecutors in pre-trial or court what significance will they attribute to it in the context of other existing facts.

The specialists from the applied psychophysiology compartment then become part of the court proceedings when they testify in court about the facts of the performed polygraph test in a specific investigation case. They clarify the principles of polygraph functioning to the court, they inform about the workflow in detail, about evaluation and recorded results. The answer professional questions of the court, eventually prosecutor's questions or the ones of the defense. In some cases it is the prosecutor himself, eventually the court, who demand the completion of the investigation file by the execution of a polygraph test. This happens especially in cases "argument against the argument", where two sides of court proceedings offer different testimonies. Both get a proposal for a polygraph test. Finally one side, normally the suspect, rejects the testing. The other party takes the test with positive outcome. This fact can contribute to simplyfication of the decision process of the court.

We have seen in the history of polygraph testing on one side the supporters of the polygraph as an effective tool, on the 
other side there were even ones who considered this method to be untrustworthy, insufficiently reliable and little scientific. They tried to doubt the results of testing by different means. Nearly twenty years of existence of the department of applied psychophysiology indicates its importance. Polygraph testing became the milestone for many in the area of criminal work, which finally gave truth to their claims, that the suspicions or different accusations, which were raised against them aren't based on truth. As the history shows, psychophysiologic detection of deception is a valid tool for credibility and realiability examination when realizing the personal politics of the Ministry of Interior of Slovak republic. The results of polygraph testing often confirm the fact, that the members of Police force perform their uneasy work in a honest, conscientious and brave way.

The compartment of applied psychophysiology has its expertial credibility, which was built on the results during many years of existence. Qualification, professionalism, the moral level of the personnel are the atributes supporting the fact, that its employees are called to different expertial consultations within international cooperation, but also within consultations of national entities dealing with this problematics. Expertial activities, the presentation of the workplace in mass media, publishing and pedagogical activity, appearences on different forums are the ways for the employees of the specialized workplace of the Ministry of Interior in which they try to bring closer the whole process of polygraph testing not only to the lay public, but mostly to the expertial public, so that the sediment of unfamiliarity, incomprehension and vagueness is taken away from this procedure.

\section{References}

1. The regulation of Ministry of Interior of SR no. 57/1998 about the activity of the department of special psychology of the personnel and social activities section of Ministry of Interior of SR mentioned in the bulletin of Ministry of Interior, part 57 from 20th August 1998.

2. The order of Interior secretary no. 172 regarding the enhancement of personnel of the designated units of Ministry of Interior of SR and Police force published in the bulletin of Ministry of Interior of SR, part 93 from $29^{\text {th }}$ November 2013.

3. Act no. 301/2005 Collection of Laws.

\section{Your next submission with Juniper Publishers} will reach you the below assets

- Quality Editorial service

- Swift Peer Review

- Reprints availability

- E-prints Service

- Manuscript Podcast for convenient understanding

- Global attainment for your research

- Manuscript accessibility in different formats ( Pdf, E-pub, Full Text, Audio)

- Unceasing customer service

Track the below URL for one-step submission https://juniperpublishers.com/online-submission.php 